\title{
A TRANSNATIONAL STUDY ON AMERICAN HEGEMONY OF INDONESIAN MALE TEENAGERS THROUGH SMACKDOWN
}

\author{
Dhionisius Bambang Gumilang \\ dhion.gumilang@gmail.com
}

\begin{abstract}
SmackDown is one of the most phenomenal products of U.S. popular culture. It goes beyond its geographical borders to broadcast in each house in other countries. It caused several deaths and injuries to Indonesian children during 2006 followed by the banning of the program from airing nationally. It began re-airing through TV cable in 2011 and fanbase communities were established in three major big cities in Indonesia, which are Yogyakarta, Bandung, and Jakarta.

This research represents the perception of SmackDown among Indonesian male teenagers ages 15-17 and its effects as well as the power of SmackDown over them. It uses a mixed method of quantitative and qualitative methods in a grounded research under Transnational American Studies related to hegemony and popular culture. The analysis of the data that are collected through quantitative method uses the semiotic approach that links the sign, signified, and signifiers to the reality by comparing it to the American perception based on the published journals, thesis, or dissertations to Indonesian perception from interviews and group discussions with fanbase members, students from three private high schools and athletes of amateur wrestling.

This research reveals that hegemonic masculinity that constructs gender in society is shaped through the broadcast of SmackDown in Indonesia. It is seen from the performance that justifies violence, portrays the ideal body for men and positions women as inferior to men. Meanwhile, the SmackDown itself engages the audience by manipulating the reality in order to blur the line between fantasy and reality. The blurred lines give the audience a sense of pseudo-ideology which puts fantasy as their reality. Gender construction is pseudo-ideology to the society.
\end{abstract}

Keywords: SmackDown, hegemony, popular culture, transnational

\section{Introduction}

The modern era has a phenomenal impact on our culture and it is getting worse. Poverty gives birth to social delinquencies and the culture of corruption to our government as well and it comes down to all staffs. It has resulted in a big gap between the government and the Indonesian, which the people get poorer and, on the contrary, it makes the people that run the government get richer. Those rich people are identical with the use of products that come from other countries especially America. It is a proof to our culture that we are ideologically colonialized even though we are in the modern era. We are no longer proud enough of our domestic products to use them. It enables us to be colonialized in the area of economy, and politics that causes our disability to determine our identity. The habit of using imported products had been begun when we lose our battle in a way of ideology wise. Our mindset assumes that those imported products are way better than the local ones. Actually, our local products have the same quality as imported ones but our habit in using them is due to the pride and prestige that comes to our society. This indicates our hegemonized society. Our devotion to using imported 
products is an ideology colony that is determined as cultural hegemony by Antonio Gramsci (Ives, 2004).

Indonesia has been hegemonized by the West specifically through Americanization in all aspects (Willett, 1989). This ideology hegemony is done by the cultural products; music, fashion, technology and even food. The fashion style has its effects on the Indonesian youth altogether with the music genres and fast food not to mention beverages, cigarettes, and media. The progress of technology that produces new cultural products in the society is in accordance with some elements in Indonesia society that preserve its local culture; the way they eat, etc. These new cultural products are shared through the media that plays its role to communicate them to a larger scale of society. The products that are produced and involved in the mass media by a large numbers are called mass culture and popular culture (Strinatti, 1995). The example of pop culture including fashion style, Hollywood films, fast food and beverages color our daily life. Using the mass media to transmit these products has been helped by the group of people who are called trendsetters, who are usually celebrities make these products even popular. Pop culture is a set of generally available artifacts: films, records, clothes, TV programs, modes of transportation, etc (Strinatti, 1995, p. 22).

The most famous sportainment in the U.S. is professional wrestling. The great success of this show is because it shows the complete package that professional wrestling offers; it has dramatic scenes, is understandable, and has novel situations that presents interesting characters, and most importantly it has a low production cost (Assael \& Mooneyham, 2010). The success of WWE hegemonizes the local audiences in countries besides the U.S. The WWE main office in Connecticut decided to open offices in London, Munich, Tokyo,
Singapore, Dubai, Shanghai, Mumbai, and Mexico City according to the data presented on the WWE corporate website. These trends need a deeper study on transnationalism and cultural hegemony because they affect the culture and patterns of youth culture, which have been exposed to the existence of media and internet.

The effects of SmackDown in Indonesia can be seen in analysis of the 14 February 2014 when Ustadz Hariri did the same moves as seen in SmackDown to attack the engineer during his speech in Bandung ${ }^{1}$. It was not shocking enough remembering that Indonesian children had become the victims of the effects of SmackDown in recent years. As reported, there was a 9years old boy died after imitating the moves performed in the show with his friends. Another report also claimed that injuries; broken bones and concussion were experienced by children all over the country. The data shows that SmackDown can affect the psychology of its viewers, more importantly children, because it portrays violence, mocking, and swearing. The recent research from LIPI done in 2007 concluded that television programs airing violence caused damages to the morality and culture of children who were not supervised by their parents (Hanim, Muchtar, Rochmawati, \& Astuti, 2007).

Experiencing the deadly effects of SmackDown; deaths and injuries to children, makes this research examining the effects on youth that were recently exposed to digital media relevant. Besides, this research will discover on the reasons why SmackDown gained its popularity and why it hegemonizes the audience.

1

http://www.tempo.co/read/news/2014/0

2/13/058553778/Injak-Kepala-Orang-

Ustad-Hariri-Menyesal Retrieved on 15

February 2015 


\section{Methodology}

This research is under Transnational American Studies using grounded research, which examines the effects of a cultural product originally from the United States, which goes beyond its geographical borders to another country. The qualitative research method is then used to present the analysis of the data in this research. Primary data has been collected using quantitative method since this is a new research topic in Indonesia and also because the object of this research is perceptions. The focus group bas been then chosen as the method used to gather the data. This is also an inquiry process to gain an understanding of social phenomenon or humanity issues (Creswell, 2009). It allows the researcher to draw a complex, big, and holistic picture, analyze words per words, report the view of the informant, as well as do the research in a natural setting. A qualitative analysis makes data collection using open-ended types of questions so that it can reveal new phenomenon or understanding. So, a researcher can explore, look in a glance, explain, or interpret part or the whole phenomenon being examined. This method could raise a new fact towards lines of phenomenon, which can then be used to negate or support the existing theory.

There are two kinds of data used in this research, primary and secondary data. The primary data is the result of focus groups and interviews with members and nonmembers of the SmackDown fan community. The students of the three private schools are treated as the nonmember of fans community as well as the amateur wrestlers of West Java centralized training. They range 15-19 years old. Meanwhile, the secondary data is gained through the journals, thesis, dissertations, and published articles that are in the same topic area of perceptions, effect, violence, or professional wrestling which are used to enrich the data and support the analysis.

Collecting the data had few steps. First, the researcher composed some questions that were used as a questionnaire to guide the focus group. The questions were collected through collecting, reading and observing the SmackDown performance as well as the journals or thesis and dissertations that support the finding to answer the research questions. After all the questions are set up, the consent from the Indonesian government is sent altogether with the research proposal and instrumentations. Conducting the focus group was easier to complete for the members of the fan community since they had a fixed schedule of gathering and they were welcoming to the researcher. Meanwhile, for the schools, the researcher had to arrange the proper date to conduct the focus group and interview. The interview questions are the continuity of the questionnaire, which enabled the interviewees to answer freely because it uses open-ended types of questions. It comprises of questions about how they see SmackDown, their perception about male and female wrestlers, why they watch television program, and their behavior or suggested idea after watching the program. The researcher asked the questions in detail without luring them into specific answers. Interviewees were chosen based on their ability to speak up in the focus group and their position in the group, e.g. the leader of the classroom, the leader of the fan community, the A students, and those who are looked up to by the others. They were chosen because their position as a leader could portray the domination towards the sub-ordinated person in the same group. All the talks and answers done in the focus groups and interviews were recorded and then transcripted. The interpretation will use thick description as presented by Ponterotto (2006) which is the development of Denzin's method to unite the thought of Geertz from 
anthropological area and philosophical, Ryles. According to Ponterotto (2006),

A thick description does more than record what a person is doing. It goes beyond mere fact and surface appearances. It presents detail, context, emotion, and the webs of social relationships that join persons to one another. Thick description evokes emotionality and self-feelings. It inserts history into experience. It establishes the significance of an experience, or the sequence of events, for the person or persons in question. In thick description, the voices, the feelings, actions, and meanings of interacting individuals are heard. (p. 261).

Analyzing a phenomenon using thick description should be able to draw and interpret the social actions done by the respondents contextually. As a result, thick description should be in accordance with thick interpretations of the social actions so that it leads to the thick meaning in the research results to reach the understanding of the respondents (Ponterotto, 2006, p. 261).

Again, according to Ponterotto (2006), data analysis is the process of reducing large amounts of collected data to make sense of them. During analysis, data is organized and reduced through summarization and categorization to make patterns and themes in the data so that it could be identified and linked. The data is collected and then it is categorized and clustered into some criteria to ease the interpretation of the data during analysis. Categorizing and clustering the data helped the researcher to know which kind of hegemony or what groups of Indonesians are negating the hegemony. It was then compared with the perception of American viewers under the same category to analyze the background of the perceptions that occurred.

\section{Findings}

The hegemonic masculinity that is revealed under this study is that violence and aggression have become the main characteristics of being masculine as portrayed in the performance. Even though it is depicted through tricks or camera playing, the audience seemed to buy it as reality. Man is considered as competitive since SmackDown mostly pits man against man in physical combat. Seen from the ideal body shape portrayed by the performers, informants in Jakarta, Bandung and Yogyakarta agreed to muscularity and body fat is not their concern as opposed to female standpoint. The use of substantial drugs; fat burner, mass gainer or amino to increase the metabolic system, is popular among men. Gym stations in these areas are filled with men lifting weight to pump their muscle. Females who sign up for gym memberships are always seen in the studio joining aerobics, philates, or yoga. They are not fans of lifting weights because their ideal body is thin with less fat and muscle. Therefore, this hegemonic masculinity leads to gender construction and popular culture products shape it. In addition to that, the idea of female fights are not accepted in Indonesia.

SmackDown is creating the illusion of violence without causing irreparable harm to one's self or opponent. Mazer (1998) asserted, "much of wrestling's appeal comes from the 'immediacy of improvisation" (p. 26). "Improvisation occurred within a rehearsed framework" and "performances created the impression of spontaneity" because the action unfolded differently in each performance (Brockett, 1984, p. 119). Wrestlers must learn to give and receive signals that cue specific moves or a series of moves. Punches, kicks, and slaps do land, but they rarely land with full force. It is helped with the camera tricks. One uses the handheld camera to capture the expression of the 
suffered wrestlers when the moves are executed. The wrestlers' take-and-give and signal-reaction with the camera tricks are supported by vocal effects to create the dramatic experience in the ring.

Their viewers are mostly male between the ages of 18-36 and this becomes a dominant aspect in this demographic of the two countries: America and Indonesia, for having the culture of violence based on the violence portrayed in every show. Evidence of America's preoccupation with the culture of physical violence is pervasive and can be found in virtually all of the entertainment as well as in the sports industry. The original sport from America that is football portrays the violence because it is a contact sport where many of the players tackle each other. The physical and body contact of each player clearly states that this violence attitude can win anything and achieve its goal. Further, the sky-rocketing sport Mixed-Martial Arts named Ultimate Fighting Championship (UFC) depicts the blood and body combat in a locked cage. It pits man against man and even woman against woman, which started in 2013 when Ronda Rousey became the defending belt in Bantamweight Women Division. She also appeared during the WrestleMania XXXI and the storyline enabled her to fight against Stephanie McMahon. The TV show rating in the U.S. also placed the series that involves physical violence at the highest rank. This rank is downloaded from the Nielsen's website. It is a private company that measure national $\mathrm{TV}$ viewing using Nielsen's People meter technology to electronically capture all viewing from their nationally projectable sample of panelists.

American society is violent not because of guns but basically because of the attitudes of Americans. When Europeans first came to the Americas, they thought that they had discovered a new world. Instead they found a land already inhabited by people with their own ways of life (Slotkin, 1985). Violence was in their souls and Americans in our present time have inherited it. Violence pervades this culture. Americans not only engage in violence, they are entertained by it. As stated by Adi (2001), "violence also appears in literary works which American literature always portrays in the discussion of factual events from recent time" (p. 87) Meanwhile, Indonesia also has the culture of violence but it is in the form of symbolic violence. Symbolic violence gains its popularity through media in Indonesia. It is not only depicted in sinetron but also through another form of media; news, music, slapstick comedy, and talk show. According to Piliang (2003), "symbolic violence comes up to the audience in forms of distortion, misleading, faking, and comedy" (p. 149) and it is found in the news portraying that media is a tool for elites to control the society as seen in news coverage and sinetron or what is known as electronic cinema. Therefore, the difference in culture between America and Indonesia about physical violence and symbolic violence is based on their history and popular culture products. Besides, the patriarchal system in Indonesia puts this symbolic violence as a clear example of gender construction.

Professional wrestling also puts muscularity as a symbol of masculinity. This televised professional wrestling show combined with all the aspects in it become part of an elaborate performance of gender, which prescribes what it means to be a man and what it means to be truly masculine. This tends to support the hegemonic ideal. Media images and messages may influence viewer perceptions of the body and may encourage viewers to internalize body image ideals. Furthermore, the exposure to idealized media body images may prompt social comparison whereby viewers compare their own bodies to the ideal and assess whether or not they measure up. Media images and messages that promote the male ideal body as big, strong and 
muscular therefore have important implications. It contributes to body image dissatisfaction among men and boys as it does among women and girls. Moreover, men who are dissatisfied with their bodies may be driven to attain the ideal and consequently may engage in behaviors that could potentially contribute to poor health such as eating disorders, excessive exercise, and abuse of substances including body supplements; fat burners and mass gainers. This indicates that the ideal male's body type is about muscle and it is different from the female's ideal body type in relation to the one. Women think that lean and athletic is good but they seem to have another reason for choosing that criteria because they emphasize health. Indonesian women always get advice from their parents about bibit, bobot, bebet, which emphasizes good health and genes are the most important aspects for them to have if they want to marry a respectable man.

The blurred lines between fantasy and reality become invisible through the rising of popular culture, which shapes the society into its pseudo-culture. SmackDown could manipulate its audience to gain more profit and make wrestling as their idea of life. Reality manipulation depicted in SmackDown comprises in putting the performance as if it is a legitimate sports combat, which has an arena, referee, rules and a championship. During its airing, sports channels become the only ones to broadcast this male soap opera. Its manipulation consists of its predetermined outcomes so that it has narrative scripts including the choreographed moves within the circle. As stated in the analysis that male wrestlers' bodies are mostly athletic with big muscles and height supported with the open-ness, their athleticism is merely a cover to legitimate the sport itself even though sportsmanship is not highly valued. SmackDown is a world of politics, a battle between good versus evil. This means that good does not always win and winning can be achieved by any means necessary. On the contrary, other combat sports like boxing and amateur wrestling, highly value sportsmanship and emphasize that the most determined and strategic athlete will win the competition.

Immortality is also presented in SmackDown. A wrestler who got bumped, body-slammed, thrown with ladders, table or chair, is able to fight back and even could do the same to another wrestler in following week. These supernatural creatures become immortal and it is different with the UFC or boxing in which blood, broken bones, and even concussions often occur accurately showing human nature. Mostly, SmackDown fans would not watch UFC or boxing because they do not want to be presented mere-human traits. Besides, SmackDown is targeting a new audience which is children by changing their program category into PG rated content. It means that they need to raise their profit because children, who love to watch live events should be accompanied by their parents. In addition to that, children are more interested in buying the merchandises such as T-shirts, hats, or mini figures of the performers.

In order to evoke a strong reaction from the crowd, a wrestler will attempt to speak to a deeply held social value with his characters as stated by Mondak (1989) analyzing the shows of the World Wrestling Federation during the late 1980s. He argued that the rise in the popularity of professional wrestling during the Reagan administration was related to the general rise in patriotic sentiment that occurred at the same time. He told the story of the Iron Sheik, a World Wrestling Federation wrestler, who portrayed a middle-eastern stereotype at a time when the Iranian hostage crisis was fresh in the minds of the American public. The lurid sagas played out for fans in the wrestling ring mesh with the ongoing sagas on television, in the movies, celebrity 
gossip and the news where 'real life' stories allow each news report to become a mini-drama complete with a star, a villain, a supporting cast, a good-looking host and a neat, if often unexpected, conclusion. It makes the whole nation can sit in rapt to watch this professional wrestling show on TV. It simply reflects the reality that actually has been made by the media through advertisements, online news, magazines, or even social media. Life, real or contrived, rather than simply invention, provides the fodder for entertainment. The problems of existence are, through the medium of entertainment, domesticated and controlled. We measure our lives by those we follow on the screen or in the ring. We seek to be like them. We emulate their look and behavior. We escape the chaos of real life through fantasy. We see ourselves as the stars of our own movies (Mondak, 1989).

As the popular culture has immersed in our daily lives, its nature to blur reality from fantasy can now clearly seen. The producers go to great lengths to mold their products to reflect the audience's beliefs and values (Nachbar \& Lause, 1992, p. 3). In television's obsession with reality, ordinary people are showcased as actors and mundane situations as drama ask members of society to see themselves as though on television. This is not the same thing as being virtual, but rather occupying a feedback loop 'live.' This is a shift in terms of how the society understands ideas such as simulation and spectacle; a shift that emphasizes, not the disappearance of reality but rather a reversal of how the problem is posed. Crandall (2003) put the situation cogently, "the reality of representation is substituted for the representation of reality. That is, authenticity arises less from the authenticity of reality per se than the authenticity of the means by which reality is portrayed" (p. 7).
Media supports this 'kayfabe' in the world of professional wrestling. They would portray the characters in and out of the ring and would not cover their personal life. As seen in the media coverage of The Rock, he would not get media attention as Dwayne Johnson when he still worked with the WWE. However, after his contract was finished, his acting in Hollywood got the media blow up and he started to go by his name, Dwayne Johnson. The company itself banned the feud wrestlers in a ring to appear together in public in order to keep the kayfabe within the world of professional wrestling. Yet, recently, the company deviated from its rule, putting social phenomenon into their storylines; childhood trauma, jealousy, and lifestyles including alcoholism or male-gazing towards women.

Use of the term fan community has most often been used to describe a group of people, often geographically dispersed who nevertheless connect around SmackDown text (Ford, 2007, p. 24). Several fans explicitly acknowledged this mode of engagement as a driving force for their continued interest (Ford, 2007, p. 25). As observed especially at these local venues with monthly or weekly events, wrestling fans have regular meetings to sustain relationships. When fans act as performers or as critics, they often do so simultaneously to emphasize their standing within the community, so that fan involvement and other modes of engagement are implicitly also about this formation of community. Based on the observation during the nonton bareng of WrestleMania XXXI in Yogyakarta and Bandung, fans often moved around seats or used intermission time to go across the venue to say hello to other fans they spotted. Many of them seemed to group together to become a 'cheering section' for favorite performers and from the reaction of the other fans, seemed to inhabit that same section of the building on a regular basis. They do this face-to-face social 
action because they are in the same place but whenever they go home, the internet and phone applications would be the means to create the social embeddedness. According to Nindyasmara (2015), social embeddedness by joining a group with the same interest is important and it is treated as a mode of survival for the individual ${ }^{2}$.

The establishment of Tough Enough and Broken Skull's Challenge gave hope to the fans and the audience that they could be one of the superstars in the ring which give them a sense of engagement that they could become like their idols with millions of dollars in income. Tough Enough is a reality show that auditions 'commoners' and gives them a chance to make their dreams come true to be performers with a contract with WWE valued at $\$ 25,000$. Each week, a participant is eliminated by the viewers through online voting. In the past, the dream life of a superstar was as far as imagination and nowadays reality TV shows make it real making the lines between fantasy and reality become invisible.

Indonesian fans joined the fan community or fansbase, held their regular meeting once per month to watch the live events or Pay-per-View videos. They gathered in a local venue and interacted with other wrestling enthusiasts. They did not often have this occasions because they could discuss the storylines or weekly matches through social media; Facebook, Twitter,

2 Nindyasmara, K. (2015). Negotiation

of Identity in Diasporic Literature: A

Case Study in Amy Tan's The Hundred

Secret Senses and Leslie Marmon

Silko's Ceremony. Unpublished thesis.

American Studies program, Faculty of

Cultural Sciences, Universitas Gadjah

Mada, Yogyakarta. and Kaskus. They gathered because they felt that they are the same, they shared the same values of honoring SmackDown as their identity differed from other Indonesians who mostly liked soccer. Social media plays an important role in shaping the culture of the society. They can change their face-to-face interaction into aclick away interaction through gadgets. Americans tend to be effective and efficient regarding social contact which they do not see each other often. For Indonesians, it was a daily basis to get together in the same place with others to chat or share their daily life as seen in gotong royong or kenduren culture. This means that pseudo-culture was already immersed into their pseudo-ideology.

\section{Conclusion}

Sport is a human endeavor that was and still is associated with predominant male participation and masculinity and is reflected throughout the sports media. The ratio of sports coverage in the media clearly reveals that whilst men appear to be losing their monopoly over the world of sports, they are still leading in securing the attention of the sports media (Szabo, 2004). If and when women are depicted, they are portrayed in stereotypical feminine roles (Wigmore, 1996), emphasizing beautifully proportionate and conditioned bodies, posing in an erotic or sexually available way. The representations include more than just bodily features but also personal characteristics such as modesty, obedience, and chastity (Hargreave, 1994, p. 160).

Popular culture manipulates the 'needs' into 'wants' as a formative 'attacking' of aspects of the society and blurs the distinction between them. If 'needs' should fill the blank space in the human's biology, popular culture often convinces the society that 'wants' are actually what human's need. Popular culture does not merely reflect society's heart and soul but 
manipulates them (Nachbar \& Lause, 1992, p. 7). Because Americans view reality through glasses tinted in red, white and blue, it means that other nations should do the same. The cultural biases then occurred when the indigenous culture was cleansed by the globalization through popular culture. As seen in the changing form of social embeddedness in Indonesia, these youths shifted their behavior from face-toface social contact into a-click or a-tweet away to meet and have the social bonding with the others.

The media has a big influence in shaping the society into whatever the editor, producers and writers want it. This is creating the pseudo-ideology of the audience as a reflection of the company vision - the more profit they gain, the more they create fantasy and make it real to the audience. Thus, it intrigues the ideology of fans who willfully want to be the spectators and critics. The Indonesian fans who gathered in their fanbases believed that whatever was presented in the performance was their identity. Ethnic culture which symbolizes the Indonesian culture is shifted into American culture which portrays the communality through digital apps and ends in the rise of pseudoideology of Indonesian youth. (Ives, 2004).

The hegemonic masculinity which constructs gender roles that emphasize dominance over inferior women is shaped through popular culture. Meanwhile, SmackDown is one of the phenomenal American popular culture products that are introduced to Indonesian culture and have changed its culture into a pseudo-culture that roots to the ideology of Indonesians. The informants in these three cities react almost the same to the airing of SmackDown which helps to show the conclusion that this gender construction is pseudo-ideology.

\section{References}

Adi, I. R. (2001). Kekerasan Dalam Sastra Amerika. Manusia dan Dinamika Budaya: Dari Kekerasan sampai Baratayuda. Fakultas Sastra, UGM, Yogyakarta: Badan Penelitian dan Publikasi Fakultas co. BIGRAF Publishing.

Assael, S. \& Mooneyham, M. (2010). Sex, Lies, and Headlocks: The Real Story of Vince McMahon and World Wrestling Entertainment. New York: Crown Publishing Group.

Brockett, O. \& Ball, R. (2004). The Essential Theatre (8th ed). Belmont, CA: Wadsworth.

Crandall, J. (2003). Unmanned: Embedded Reporters, Predator Drones and Armed Perception. CTHEORY 4/9/2003. Accessed at www.ctheory.net. Retrieved on June $14^{\text {th }}, 2015$.

Creswell, J. W. (2009). Research Design: Qualitative, Quantitative and Mixed Methods Approaches (3rd ed.). Thousand Oaks: Sage Publications, Inc.

Ford, S. (2007). Pinning Down Fan Involvement: An Examination of Multiple Modes of Engagement for Professional Wrestling Fans. In the materials of the MIT Program in Comparative Media Studies 2007. Retrieved from http://ocw.mit.edu/OcwWeb/Compar ative-Media-Studies/CMS997Spring2007/DownloadthisCourse/index.ht $\mathrm{m}$

Hanim, M., Muchtar, R., Rochmawati, R., Astuti, S.I. (2006). Dampak Tayangan Pornografi, Kekerasan, dan Mistik di Televisi. LIPI: Jakarta.

Hargreave, J. (1994). Sporting Females: Critical Issues in the History and Sociology of Women's Sport. London: Routledge.

Ives, P. (2004). Language and Hegemony in Gramsci. New York: Pluto Press. 
Mazer, S. (1998). Professional Wrestling: Sport and Spectacle. Mississippi: The University Press of Mississippi.

Nachbar, J. \& Lause, K. (1992). Popular Culture: An Introductory Text. Ohio: Bowling Green University Press.

Nindyasmara, K. R. (2015). Negotiation of Identity in Diasporic Literature: A Case Study in Amy Tan's The Hundred Secret Senses and Leslie Marmon Silko's Ceremony. Yogyakarta: Unpublished.

Piliang, Y. A. (2003). Hipersemiotika: Tafsir Cultural Studies Atas Matinya Makna. Yogyakarta: Jalasutra.

Ponterotto, J. G. (2006). Brief Note on the Origins, Evolution, and Meaning of the Qualitative Research Concept "Thick Description". The Qualitative Report Vol. 11 No. 3, Sept 2006, pp. 538-549.

Slotkin, R. (1985). The Fatal Environment: The Myth of the Frontier in the Age of Industrialization. Middletown, CN: Wesleyan University Press.

Strinati, D. (1995). An Introduction to Theories of Popular Culture (2nd ed). London: Routledge.

Wigmore, S. (1996). Genre and Sport: The last 5 years. Sport Science Review 5:53-71.

Willett, R. (1989). The Americanization of Germany, 1945-1949. London: Routledge. 